\title{
Quality Control of Steel Reinforcement Works For Contractors
}

\author{
$1^{\text {st }}$ Putri Lynna Adelinna Luthan ${ }^{1}, 2^{\text {nd }}$ Nathanael Sitanggang ${ }^{2}, 3^{\text {rd }}$ Bambang Hadibroto $^{3}$ \\ \{putri.lynna@unimed.com ${ }^{1}$, nathanaelsitanggang@ unimed.com ${ }^{2}$, hadibroto@yahoo.com ${ }^{3}$ \}
}

Faculty of Engineering, Universitas Negeri Medan, Indonesia ${ }^{1,2,3}$

\begin{abstract}
This study aims to determine the indicators of quality control that can be used as a reference to control the quality of reinforcement work. The research was conducted in the Medan city with survey method. The research sample used was a multi-storey building construction project in the Medan city with a total of 20 construction projects using purposive random sampling method. The research instrument was a field supervisor's guide and interviews developed by the research team. The research data obtained were analyzed using descriptive statistical analysis. The results of the study show that the indicators for contractors to carry out reinforcement work in accordance with specifications and good work methods are as follows: 1) The planning stage consists of a working drawing starting from for construction, detail drawing, shop drawing and Bar Bending Schedule (BBS). 2) The manufacturing stage consists of: determining the project schedule, monitoring the availability of steel, manufacturing, cutting and bending. 3) The installation stage consists of: Shop Drwaing, installing reinforcement according to drawings and BBS codes, checking installation and calculating volume for assessing the work progress.
\end{abstract}

Keywords: supervision, quality, reinforcement, work drawing.

\section{Introduction}

Reinforced concrete in construction projects is the most widely used material, therefore the factors that affect the strength of reinforced concrete need to be considered starting from the planning and implementation stages. Many reinforced concrete works cause building failures and construction failures that caused by technical and non-technical factors. Failures due to technical factors occur because of irregularities in the implementation process that is carried out not in accordance with the agreed technical specifications. Failure due to nontechnical factors are caused by weak supervision in the isntalation process, so that it can cause accidents and losses. A accident due to reinforcement work that recently occurred was the collapse of the pile cap due to the arrangement of the reinforcement not being bound by rebar tie wire that occurred in bridge work in Banjarmasin [1]. This accident was caused by nontechnical factors, weak supervision or control from the contractor as the executor of the construction carried out in the unfinished reinforcement process so that there was no information in the field that the work had not been completed. As a result of the work accident, the reinforcement will be damaged and cannot be used anymore. This will certainly hinder the implementation of further work, according to the results of research conducted [2], the cause of delays in construction projects is due to poor organization and rework. Another thing that often occurs in reinforcement work is an increase in the remaining steel material 
used, based on research conducted [3] reinforcement steel material in the field produces $20 \%$ of the total cost of the rest of the material. In 2005 there was an increase in the remaining concrete material by $34.86 \%$ [4], and in 2007 according to Figures [5] there was a significant increase of $52.38 \%$ of the total cost of the remaining material. The amount of material costs remaining in the reinforcement work is certainly a concern for what causes this to happen. Intan et.al stated that the cause of the remaining reinforcement steel material can be seen from the four stages of work, namely: design stage, material procurement stage, material handling stage and implementation stage. This is supported by [6], the remaining factors in the field are caused by the cutting process, cutting planning, material storage. The cause that often occurs due to reinforcement work is the high residual steel produced due to the contractor's lack of knowledge in managing reinforcement work. The knowledge that needs to be possessed as an executor of reinforcement work is: 1) mastering the specifications of reinforcement and working drawings, 2) mastering work instructions and 3) mastering project work schedules. In addition, the contractor in carrying out the reinforcement work does not make standard drawings/detail drawings that function to determine standard hooks, minimum bend diameter, the distance between reinforcement, of the several factors that must be carried out in the work of steeling/reinforced concrete, the appropriate stages/procedures will be investigated to minimize accidents, losses and the use of steel materials.

\section{Method}

Reinforcement work has an important role in the strength of building structures that are often found in foundation work, sloof, columns, beams, floor plates and stairs. Concrete steel is known as reinforced concrete which is resistant to tensile strength, so that the moment forces that occur in the construction can be held well. The function of reinforcement in concrete is to withstand tensile forces, shear forces and torsional moments. To produce quality reinforcement, the planning and implementation process should be carried out with technical specifications and working drawings that have been planned by the structural planner consisting of: diameter size of reinforcement, quality of reinforcement, the quantity of reinforcement and placement/installation of reinforcement. For the reinforcement work to produce the appropriate quality, then reinforcement work is carried out in accordance with technical specifications and working drawings produced by structural planners based on SNI2847-2013/PBI 1971 which produces: 1) diameter size of reinforcement, 2) quality of steel, 3) quantity of steel, and 4) placement of reinforcement. The results of the structural planner become a reference for the contractor in preparing standard drawings/detail drawings that will be used as working drawings. Research conducted by [7] maturity in making working drawings as a determinant of rework construction projects is an important role so that work does not repeat itself. To avoid material waste, the usage of steel material needs to be carefully planned by making a list of reinforcement bending patterns which include diameter, shape, length and number of reinforcement commonly known as Bar bending schedule. (BBS). For BBS calculations can be done quickly, software application tools are needed so that calculations can be carried out quickly and precisely. The results of research conducted by [8] with a visual basic program, [9] an excel solver program, [10] using a visual basic 6.0 application and [11], using a macro excel application for Bar Bending Schedule work (BBS) in determining the amount of reinforcement, reinforcement model, dimensions, code and 
remaining material. The use of the application is based on drawings produced by planning consultants called For Construction Drawings.

This study aims to determine the quality control indicators of work quality control which is focused on reinforcement works so it can be used as a reference for contractors on reinforced concrete work. The research method used is descriptive qualitative method. According to the statistical data of Medan City, there are 363 General Contractors. However, there are only 120 contractors involved in construction projects and only 20 contractors who have supervision guidelines and supervise steel work properly. The research sample was determined by purposive randomize sampling technique. Then sample in this study, there were 20 construction projects managed by the Contractor. Data collection techniques were carried out using supervisory guidance in the field and interviews. The validity of the instrument in this study is based on content validity. The data analysis technique used is descriptive qualitative analysis technique.

\section{Results And Discussion}

The indicators for the implementation of reinforcement work can be done by: 1) The planning stage consists of drawings that include construction drawings, detail drawings, shop drawings and Bar Bending Schedule (BBS). 2) The manufacturing phase consists of: determining the project schedule, monitoring steel stock, manufacturing cutting and bending. 3) The installation stage consists of: working drawings, installing steel according to working drawings and BBS codes, checking installation and calculating volume for assessing work progress which can be seen in Figure 1.

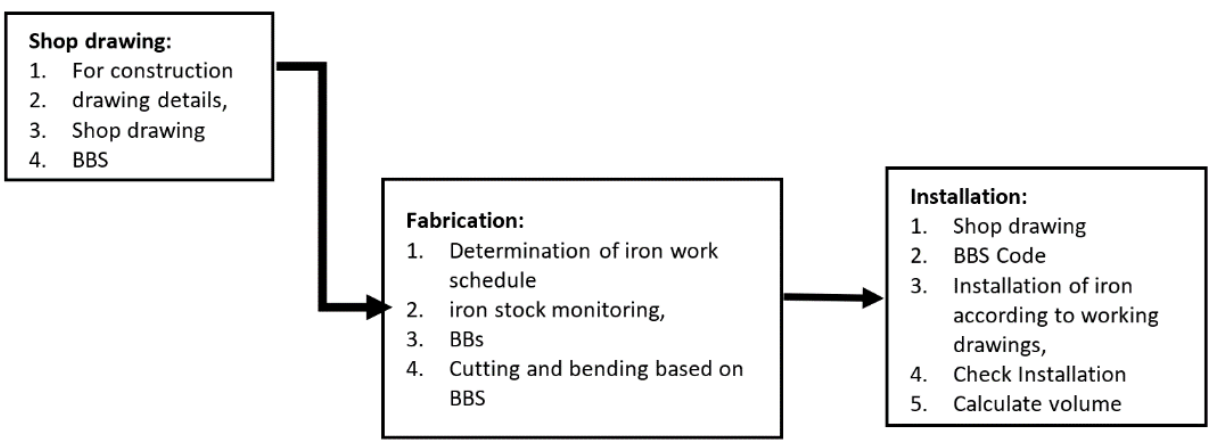

Fig. 1. Reinforcement Works Stage.

Working drawings are carried out for the planning stage which functions to calculate the quantity used to calculate: steel needs, labor requirements, tool requirements, time estimates and cost allocations used for reinforcement work. The drawing for construction is the final image that can be used as a reference for work in the field. Next, a detailed drawing is drawn which provides the smallest detail information on the design that looks more detailed, starting with the dimensions of the smallest parts, material selection, to the brand of the material used. In the detailed drawing of the reinforcement, several things that must be considered, namely: 1. The thickness of the concrete cover 2. Placement of reinforcement 3. Bending of 
reinforcement 4. Length of distribution 5. Overlay connection. Detail drawings serve as a benchmark for the quality of reinforcement work based on calculations from planners that produce strength against reinforcement, to minimize accidents to reinforcement work. After the drawing for construction, the next detailed drawing is the shop drawing job. Shop drawings are communication media between planners and implementers that contain details of making construction components that refer to drawings for construction and are used in the installation process to facilitate the installation process carried out by contractors and obtain approval from field supervisors. The approval approved by the supervisor will be a reference for making a Bar Bending Schedule or a list of reinforcement bending.

The next stage is the manufacturing process, a schedule is needed to carry out reinforcement work which serves to determine when to use steel according to needs based on the work schedule. In order for the steel bending process to run according to schedule, it is necessary to monitor the availability of steel which functions to see the availability of steel for which the reinforcement will be bent. After everything went smoothly, it was continued with the BBS work, namely making a list of the bending of the reinforcement which serves to determine the amount of reinforcement, the model of reinforcement, dimensions, codes and the rest of the material that can be used for making reinforcement with different patterns. Cutting and bending are carried out in accordance with the cutting list and steel bending by BBS and assembling reinforcement is carried out.in Figure 2.

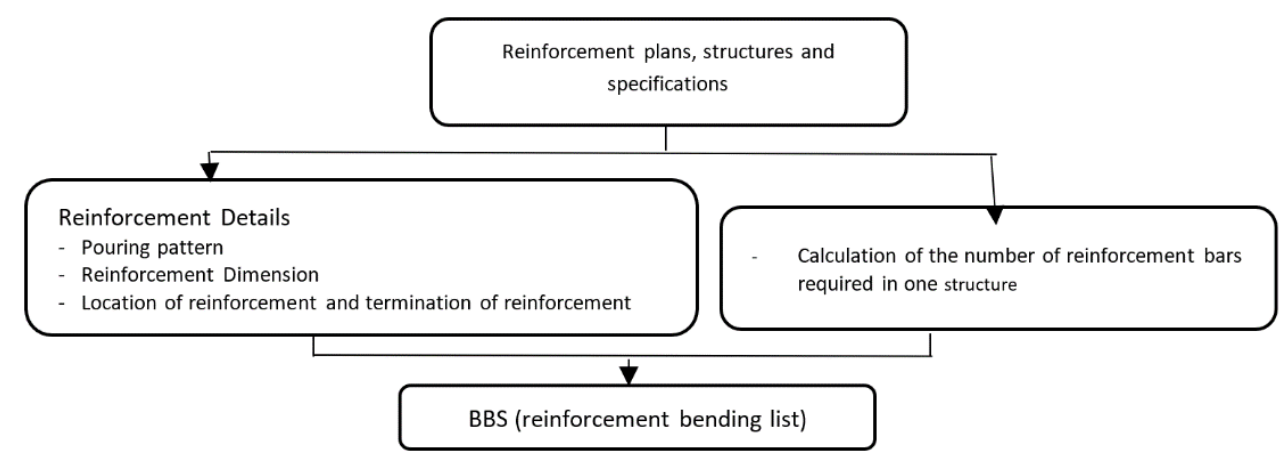

Fig. 2. Stages of BBS.

The next process is the installation of reinforcement based on working drawings and BBS. Before the reinforcement work is carried out, it is necessary to pay attention to the checklist form of the formwork work and the reinforcement work that has been checked by the supervisory consultant. Before being covered by formwork and casting, the installed reinforcement must be maintained so that it does not fall and roll over, such as the addition of steel supports to maintain stability and concrete decking as a form of a concrete blanket. At the formwork stage, if reinforcement has been installed to ensure the formwork is truly in accordance with the desired shape, pay attention to the precision, stability and stiffness of the formwork by looking at the indicators of sturdiness, connections, treads and formwork mounts, then pay attention to leaks with indicators of connection tightness, disconnection of castings, and neatness of pipe sparing. [12] Then make sure the reinforcement is as planned and check if the water stop is installed to maintain the Water Cement Factor (FAS) of the concrete. The next work is casting by paying attention to 3 stages that must be carried out, namely the preparation, implementation and finishing stages [13] The inspection carried out at 
the preparation stage is the need for concrete volume, determining the quality of concrete, working roads (mobilization of ready mix), placement of equipment, preparation of labor and casting schedule. The implementation stages are: determination of the casting path, Slump testing, making of test objects, croton/concreting and compaction. The finishing stage is doing finishing, maintenance, removal of supports and opening of the mold. The workflow process for reinforced concrete work can be seen in Figure 3.
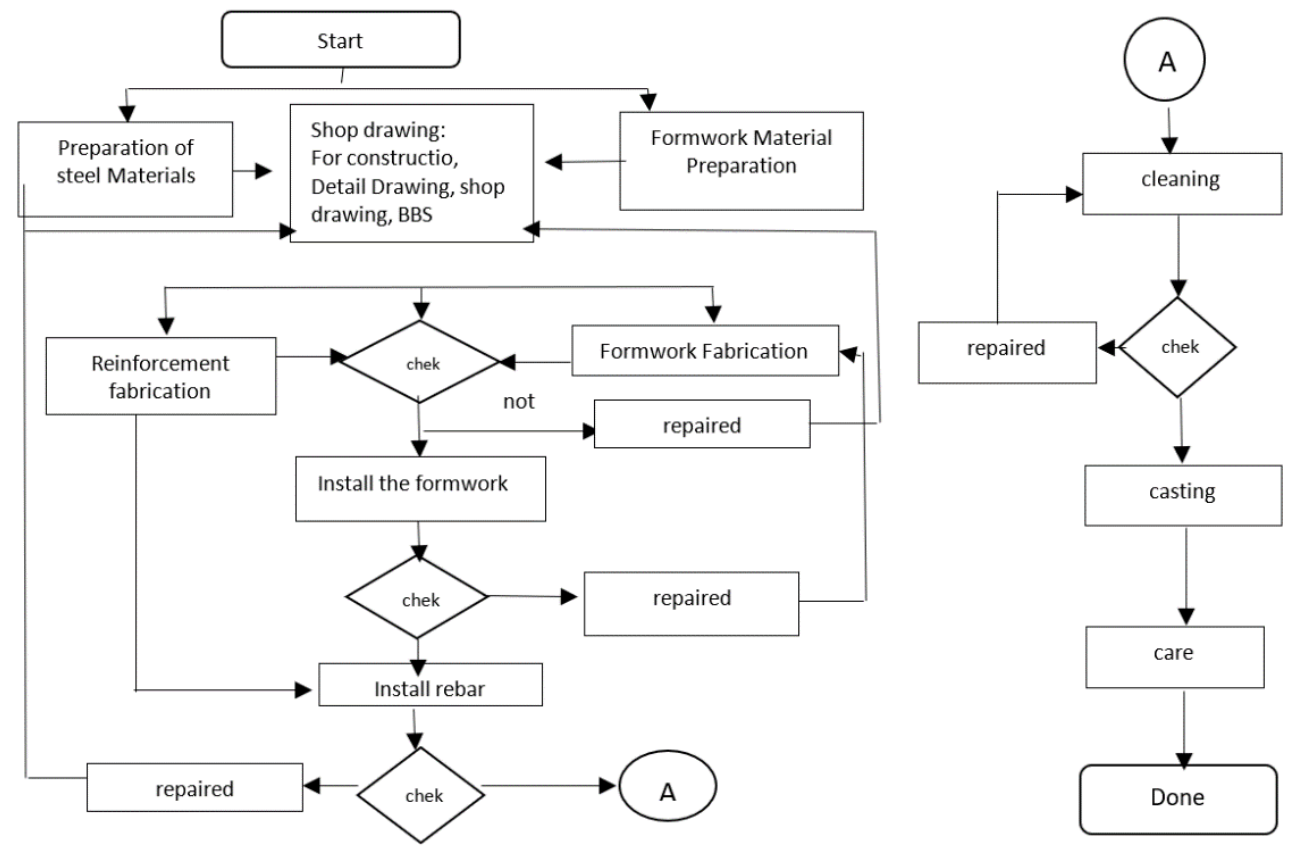

Fig. 3. Flowchart of Formwork, Reinforcement and Casting Works.

\section{Conclusion}

The stages of the reinforcement work carried out by the contractor can be carried out as follows: 1) Planning Stage. The planning stage starts from the availability of working drawings consisting of drawings for construction, detailed drawings, shop drawings and Bar Bending Schedule (BBS). 2) Manufacturing Stage. The manufacturing stage starts from determining the schedule for reinforcement work and reviewing the availability of steel in the field, then manufacturing cuts and bending based on BBS. For formwork fabrication, it is adjusted to the size of the job. 3) Installation Stage. The installation stage starts from the availability of shop drawings which will be a reference for the location of steel installation, formwork and casting. 


\section{References}

[1] maknanews.com. Robohnya tulangan project jembatan HKSN bukan gagal construction. Available from: https://maknanews.com/2020/09/24/robohnya-tulangan-project-jembatan-hksn-bukan-gagalconstruction/2/ [Accessed: $3^{\text {rd }}$ July 2021]

[2] Magdy AM, Georgy M, Osman H. Ontology-based investigation of construction delay analysis methodologies in Egypt. Alexandria Engineering J. 2016; 55(2):1515-1539.

[3] Formoso CT, Sobeilman L, Cesare CD. Material Waste in Building Industry: Main Causes and Prevention. J Constr Eng Manag. 2002; 128(4):316-325.

[4] Intan S, Alifen RS, Arijanto L. Analysis and Evaluation of Construction Material Waste: Sources of Cause, Quantity, and Cost. Civ Eng Dimens. 2005;7(1):36-45.

[5] Figures Y. Strategy to Minimize Construction Material Remaining in Multi-storey Building Construction Projects Implemented by State-Owned Enterprises Contractors in Indonesia. Jakarta: Unpublished undergraduate thesis, University of Indonesia; 2007.

[6] Lu W, Yuan H, Li J, Hao JJL, Mi X, Ding Z. An Empirical Investigation of Construction and Demolition Waste Generation Rates in Shenzhen City. Waste Manag. 2011; 31(4):680-687.

[7] Immanuel R, Yuwono BE. Kematangan Shop Drawing sebagai Penentu Pekerjaan Ulang (Rework) Proyek Kontruksi. J Cons Eng Sustain Dev. 2020; 03(1):42-48.

[8] Wirawijaya H. Pile Cap Planning Based on SNI 03-2847-2002 Method Using Visual Basic 6.0 Program. J Civ Eng. 2011.

[9] Kork M, Hartono W, Sugiyarto. Perhitungan Kebutuhan Tulang Besi dengan Memperhitungkan Optimasi Wasste Besi pada Pekerjaan Balok dengan Program Microsoft Excel. e-J Matriks Teknik Sipil. 2013:290-295.

[10] Hartono W, Wardani PK, Sunarmasto. Rancangan Program Aplikasi Shop Drawing Penulangan Struktur Kolom Penampang Segi Empat dan Pondasi Foot Plate dengan Visual Basic 6.0. e-J Matriks Teknik Sipil. 2014:553-561.

[11] Luthan PLA, Sitanggang N. Supervision Indicator of Formwork on Reinforced Concrete. J Phys: Conf Ser. 2020; 1477:1-8.

[12] Luthan PLA, Sitanggang N. The Use Of Excel Macro Feature On Cost Estimation Calculation. In: Sriadhi S, Silitonga E. ACEIVE 2019. Proceedings of the $3^{\text {rd }}$ Annual Conference of Engineering and Implementation on Vocational Education; $16^{\text {th }}$ November 2019; Universitas Negeri Medan. EAI; 2019.

[13] Luthan PLA, Sitanggang N. Monitoring Factors in Quality Control of Reinforced Works. J Phys: Conf Ser. 2018; 1179:1-7. 